\title{
The ruptures in our rainbow: Reflections on teaching and learning during \#RhodesMustFall
}

\author{
Mlamuli Hlatshwayo \\ School of Education, University of KwaZulu-Natal \\ Corresponding Author: HlatshwayoM@ukzn.ac.za
}

(Submitted: 19 October 2021; Accepted: 21 October 2021)

\begin{abstract}
In this paper, I attempt to explore and theorize the "ruptures" in our rainbow nation through foregrounding higher education in general and teaching and learning practices in particular. I rely on Morrow (2009), in particular his intellectual and philosophical contributions on epistemological access to make two contributions. Firstly, I argue that the South African higher education urgently needs to re-conceptualize the theoretical understanding of "access" beyond formal, simplistics notions. Secondly, I hope to show how an re-adoption of Morrow's understanding of epistemological access can enable progressive engagements between academics and students in both having respect for and a critical understanding of the different disciplines and knowledge(s) in higher education. I suggest that a return to Morrow' $s$ idea of epistemological access will not only enable us to make the make the necessary "repairs" to our rainbow nation but it will also enable us to better respond to the progressive and innovative calls in teaching and learning that contemporary South African higher education greatly demands of us.
\end{abstract}

Keywords: \#RhodesMustFall, higher education, Morrow, Rainbow nation

\section{Introductions}

There is a broad consensus that the "rainbow nation" in South Africa and its attempt at social cohesion is in trouble (Chikane, 2018; Kunene, 2017; Sizemore-Barber, 2020). Fanon (1963) has cautioned us about the "pitfalls of national consciousness" regarding the protracted and structural challenges that postcolonial states often face when negotiating a new form of democratic governance and society. South Africa is no different. In this paper, I locate the challenges and struggles within higher education to the broader South African society in alluding to the "public good" conception of universities. I think through and theorize South African higher education as part of the broader collective of the South African society and thus what occurs in society and its challenges has material effects for the institutions of higher learning themselves. The two cannot be analytically or conceptually separated from one another. They 
exist with and through each other. One of the most powerful posters held up by the protesting university students during the 2015-2016 \#RhodesMustFall protests was a signage that read,

'Our parents were sold dreams in 1994... We are here for a refund!!!' (Badat, 2017: 6). This signage was no doubt provoked by what is often seen as the failure of the then "Mandelian miracle" to live up to the ideal of providing a "better life for all" and ensuring some form of upward social mobility for the millions of Black South Africans who are still trapped in structural and inter-generational poverty. Commenting on the failures of the rainbow nation, Kunene (2017) suggests that

The 'rainbow nation' made us believe that even within our differences we are equal. But we are not. We live in a country with the highest wealth inequality in the world. All political freedom did was make us seemingly equal in identity as South Africans [and even then, only just]. It turned a society of fundamental inequality into a society of nominal equals. And because we are all 'equal', all infinitesimal Pantone variations of a rainbow, it requires that we, in effect, ignore the real things that divide us. An uncritical lens allows the rhetoric of the rainbow nation to go unquestioned. The concept of the rainbow nation was an idea that our parents and grandparents could believe in. Needed to believe in. The promise of a 'rainbow nation' was [and is] so much better than the brutal, unflinching unrelenting reality of Apartheid beatings, rapes, tear gassing, killings, oppression and daily terror.

Kunene challenges the fallacy of the rainbow nation as a deeply flawed project that ought to construct a hegemonic national identity for South Africa while de-emphasizing structural inequality regarding race, gender and class. Although deeply contested and at times debunked, there was broad consensus beginning at least in the early 1990s that South African society was filled with the elusive ideals and dreams of the then incoming democratic dispensation that was articulating the gospel of democratic change, societal transformation and socio-economic restructuring (see for example Badat, 1994; Beall, et al., 2005; Bond, 2014). The emergence of the discourse of the "rainbow nation" was accompanied by the presupposed understanding that a new country was to be re-born, and that this "new" South Africa would fundamentally break from the racist and racialized logic of apartheid, and would foster diversity, social justice and democratic tolerance in its foundation (Baines, 1998b). This resulted in the African National Congress (hereafter the ANC) government and President Nelson Mandela then encouraging the ritual celebrations of the rainbow nation at the 1995 Rugby world cup. Perhaps most prominently, this discourse was made famous by the then chairperson of the Truth and Reconciliation Commission, the Archbishop Desmond Tutu who often spoke about the 'rainbow people of God' (Baines, 1998b). What was interesting about the Tutu moment in relation to the emergence of the rainbow nation, was that as a cleric, his image presumably signified the Old Testament story of the flooding in which the rainbow symbolizes God' s promise not to pass further judgment to the world (Baines, 1998a, 1998b, 2007). Thus the rainbow nation represented some form of diversity, tolerance, radical change and democratic tolerance in the country. In her 
article titled, Being a Feminist in the Fallist Movement in Contemporary South Africa, Mazibuko (2020) adopts a feminist lens to largely critique the fallacy of the rainbow nation in continuing to oppress, harass, and dispossess Black working class students from the academy. She argues that the rainbow nation does not accommodate or take account of Black life and Black politics, and thus we need to expose its epistemic/ontological/existential limitations. It should be noted that this flawed conception of diversity and democratic tolerance, premised on largely "forgiving the sins of apartheid" sought to further entrench the racialised and structural divisons in South Africa, that continue to haunt the country.

Reflecting on the then ten year review of the democratic dispensation, Beall, et al. (2005) argued there were two potential alternatives for the rainbow nation in general and social cohesion in particular we would all need to confront. One approach, the social disintegration path, would result in the collapse of the South African state and the entrenchment of inequality. The second approach, the "high level equilibrium" , denotes the achievement of inclusive growth and a gradual improvement in the standard of living for the citizens. More recently, I argue, three major works have attempted to make sense of South African society from different social lenses and grappling with the potentiality of the failed rainbow nation and what it means for the subaltern and the marginalized other. The first major work is The Fall of the ANC, by Mashele and Qobo (2014), in which they shed a spotlight on what they refer to the "false optimism" of the ANC government in fulfilling the demands of the freedom charter. Mashele and Qobo (2014) argue that because the party spent at least three decades as an underground movement fighting the struggle for self-determination, they did not properly conceptualize and think through what governing a complex country and the needed policy would look like. This results in the authors asking two questions in the book, 1) was the ANC ready to govern in 1994? And perhaps more importantly, 2) has the more than two decades in power given the party adequate experience in effectively and efficiently governing? The resounding answers to both questions appears to be a firm no. They offer a sharp critique at the false optimism that came with the political compromise between Nelson Mandela and F.W. De Klerk in their failure to build the rainbow nation and establish some coherent social cohesion in the country. Although largely one dimensional in only looking at the ANC singularly and not as existing within the broader national and global structures, the authors do nonetheless provide a historicized account of the crisis that is crippling the ANC and the need for South Africa to re-imagine its mode of politics beyond the ANC. Adopting a similar approach, Pithouse (2016)' s reflections on challenges confronting the rainbow nation is much more broader and transnational than Mashele and Qobo (2014). For Pithouse (2016) the challenges that are facing South Africa are not necessarily local and national in character, but can also be seen in Haiti, the Palestinian occupied territories, United States, and other parts of the world that are broadly confronting the crisis of racialized capitalism as a result of the post-Cold War moment. Unlike Mashele and Qobo (2014) who focus only on the declining influence of the ANC and its inability to reconstruct a cohesive and socially justice political project, Pithouse (2016) suggests that the domestic crisis is also seen with global crisis of capitalism, rising emergence and influence of "strong men" such as Brazil' s Jair Bolsonaro, former United 
States president Donald Trump, India' s Narendra Modi, Russia' s Vladimir Putin, the Philippines' s Rodrigo Duterte, and other leaders who rely on authoritarian forms of populism and crude nativism to govern, and silence (Pithouse, 2016). For Pithouse, the crisis of the rainbow national is transnational in character and demands that we look at the challenges facing South African society across the lines of nation-building, crime, corruption, authoritarian nationalism and others. Although Pithouse does not offer any solution (real or theoretical) on what transnational forms of nation-building or critical citizenship looks like, he does nonetheless provide the tools to think through to what extent the nation-building challenges that South Africa is facing could make sense at a global, transnational level.

Wa Azania (2014) offers a painful and sharp rebuke at the notion of the "born free" generation that although are born outside of a constitutionalized apartheid framework, are nonetheless shackled in racialized poverty and are structurally trapped in the townships. What makes Wa Azania (2014)' s work illuminating in understanding the "ruptures" in the rainbow nation, is that unlike Mashele and Qobo (2014) and Pithouse (2016)' s work, she offers this book as a letter written to the ANC on the failure of the governing party in propagating a misleading discourse of the rainbow nation and their inability in responding adequately to the abject poverty, sexual violence and the epistemic violence deeply embedded in the former model $\mathrm{C}$ schools.

Thus far, I have only critically engaged with and mapped the notion of the "rainbow nation" and the extent it is deeply contested and challenged in South African society. I now move to thinking through the crisis of South African higher education, shedding a spotlight on what I term the "underbelly" of the \#RhodesMustFall movement.

\section{On the underbelly of \#RhodesMustFall moment}

The \#RhodesMustFall emerges in the 2015-2016 moment when students rose up against what they saw as the institutionalized and deeply entrenched coloniality and whiteness in the university (see also Alasow, 2015; Maxwele, 2015; Ngcobozi, 2015). The students sought to critique and dismantle the colonial nature of institutional culture(s) at universities, outdated teaching and learning practices and the need to re-center African and global South epistemic traditions in the higher ducation curriculum design and its imaginations (see Mbembe, 2016; Heleta, 2018; Hlatshwayo \& Fomunyam, 2019). While it should be noted and recognized that Black students have been protesting in historically Black universities since at least the early 1990s and early 2000s, what made the emergence of the \#RhodesMustFall particularly different was the systemic manner in which students from different higher education institutions managed to coordinate, align and be in solidarity with one another.

As mentioned earlier, the existential crisis facing the rainbow nation is also seen with the higher education sector in the struggles to respond to the questions on the purposes of a university in post-apartheid society. The "underbelly" of the \#RhodesMustFall movement is in a way, a broader reflection of the underbellies of the South African society, manifesting itself in the higher education (Maxwele, 2015; Naicker, 2016; Valela, 2015). While there is significant consensus in the field that universities need to transform into inclusive and democratic spaces 
(Heleta, 2018; Hlatshwayo \& Alexander, 2021; Mbembe, 2016), little is often provided as to what this "transformed" or "decolonized" university/curriculum/pedagogy could potentially look like. In this section, I provide a (brief) outline into what I term, the "underbelly" of the \#RhodesMustFall moment, regarding some of the violences, intimidation, assaults, arson and others that are often overlooked and under-emphasized in higher education. I argue that different forms of violence(s) (physical/epistemic/cultural/economic) not only need to be understood in their context, but that they also begin to undermine the broader calls for transformation and decolonization of higher education in South Africa. I argue that seeing the "underbelly" of the \#RhodesMustFall allows us not only to have a critical understanding of the movement and its contribution, but it also allows us to think through possible epistemic solutions that could respond to the crisis facing higher education - mainly re-claiming Morrow's (2019) notion of epistemological access as a pedagogical approach in higher education.

Although \#RhodesMustFall, \#OpenStellenboschCollective, the Black Student Movement, and other students protests have largely been progressive in their calls for transformation and the decoloniality of curriculum and its hidden nature, assessment practices, teaching and learning methods and their approaches, re-centering the often forgotten experiences of disabled/differently abled students, access to formal higher education and others (see for example Badat, 2017; Heleta, 2018; Mbembe, 2016). The "underbelly" of the \#RhodesMustFall moment has also been seen with the militarization of South African higher education, the normalization of different forms of violence, intimidation and assault on campus. In this paper, violence and the operational function of violence, is conceptually understood as referring to both physical forms of violence as well as the epistemic forms as prevalent in curricula and in pedagogical practices (see for example Samuel, Dhunpath, \& Amin, 2017). I should emphasize that I am not suggesting that the emergence of cognitive and physical forms of violence in South African higher education started with the 2015-2016 student movements. Rather, I argue that it was the increasing militarization, disruptions, assaults and intimidations during and after the 2015-2016 student movement that I seek to explore and locate to the broader crisis of the rainbow nation. Furthermore, I also begin to propose some epistemic solutions regarding the use of Morrow' s epistemological access as a necessary pedagogical response to society in general and South African higher education in particular.

Commenting on the importance of violence in decolonizing South African universities, Manzini (2016) suggests that violence is a necessary response in tackling a colonial structure that seeks to reject their humanity as Black students. For Manzini (2016), violence is a necessary "response to a colonial structure that is violent in a structural and subliminal manner, hence the act of decolonisation will also be violent. We should note that violence should not be regarded as irrational but it is indeed necessary, violence becomes the tool towards a new humanism" . Manzini' s argument on the political role played by violence in the decolonisation process, is similarly echoed by Ndlozi (2015), in his article titled, In Defence of Black Violence, in which he justifies the use of violence in South African higher education by the Economic Freedom Fighters (EFF) against Black students: 
This argument says that when engaged in the struggle for decolonisation, or the liberation of black people, you must never be violent to other blacks. This is because the objective is to unite blacks, thus, when they attack you run away. This is flawed on many levels, the least of which is that it treats blacks as homogeneous and this goes against all of Steve Biko' $s$ work on the black condition and how we must engage in the politics of decolonisation.

For both Manzini (2016) and Ndlozi (2015), the role of violence is that it is employed in ensuring that the colonial nature of South African higher education is dismantled. Violence and the role of violence is conceptually understood as playing a revolutionary discursive role in reasserting the dignity of the "colonized" in higher education in an attempt at re-claiming their dignity in what is understood be to an alienating and marginalizing space. Although Fanon (1963), in his chapter On Violence in the Wretched of the Earth, was speaking about the violent nature of colonization and how the colonized have an ethical and political obligation to respond to it, Manzini (2016) and Ndlozi (2015) nonetheless believes that violence and its brutality could be used as a legitimate mode of engagement in institutions of higher learning. Largely influenced by the chilling slogan, "Burn to be Heard!" (see Duncan, 2016), some students in higher education seem to believe in the fallacy of the emergence of a new, transformative and decolonial institution that will emerge out of the confines of the collapse of the contemporary higher education systems (Duncan, 2016; Manzini, 2016; Nicolson, 2016). This was especially seen in how in 2016, were more than 10 public universities had their infrastructure/residence/dining hall/library burned down (Wa Azania, 2016). This included classes that were (and to some extent, still are) violently disrupted, with academics and students been chased out in an effort at derailing the academic programme so as to get the attention of the university and its management (Njilo, 2019). Combining the violence of the rainbow nation and the structural, epistemic violence of higher education in general and historically white universities in particular, Valela (2015) speaks about the "post-Marikana moment" in South Africa and what it symbolically means for the relationship between the state, universities, and violence:

This wave of campaigns waged by students across the country is also happening at a time in South Africa' s history where we are dealing with more than just the post-Apartheid moment. We are in the post-Marikana moment. After 1994, it seemed highly unlikely (if possible) that a group of human beings would be shot and killed by state police considering the nation' $s$ history of police brutality under an unjust Apartheid regime. However, we are dealing with the reality that the colonial structure is not dismantled; therefore it should not come as a surprise that protest would be met with such violence (Valela, 2015).

The simplistic understanding on the role of political violence in higher education transformation is misleading and misplaced as it results in the burning of costly university infrastructure, residence accommodation, university libraries and others, which sets back the 
university and further delays the academic project. Thus one asks, to what extent does calling for transformation through physical forms of violence, anger and intimidation help achieve the noble goals of institutional change and decolonization? Manzini (2016), Ndlozi (2015), and Valela (2015)' s justification on the legitimate use of violence in higher education, results in the social construction of a discourse that enables students to see violence and intimidation as legitimate tools to replace negotiation and the critical contestation of ideas in higher education. This was seen in the University of KwaZulu-Natal, when students attacked and assaulted lecturers after they had failed their exam:

Students at UKZN' s Pietermaritzburg campus are attacking and intimidating lecturers if they get failed or disqualified from sitting their exams, and lecturers say they live in constant fear. An investigation by The Witness has found reports of students kicking, shoving and intimidating lecturers. At least one student was formally disciplined by the university this year for sending threatening e-mails to a lecturer. The student faced six counts of contravening the university' s rules for harassing the lecturer causing them to reasonably believe that he was in danger of being harmed $\cdots$ In the last two months, there have been at least three incidents of lecturers being intimidated, including death threats, and — in one case that The Witness has verified — being assaulted by students $\cdots$.Lecturers said some acts of intimidation are brought on for academic reasons, such as students failing to meet duly performed (DP) requirements, which would bar them from writing exams, to disagreeing with scheduling of tests (Pillay, 2018).

In the above quotation, Pillay (2018) details the pitfalls and challenges that academics need to navigate when dealing with students, as their failure may results in the use of violence and intimidation. He details the coalescing of both physical and insidious forms of violence in how academics need to be constantly aware of the existential danger that they are facing when confronting students, and that they need to ensure that they are careful either not to provoke the students or fail them so as to avoid death threats, intimidation and possible violence. These South African higher education acts of violence are often accompanied by justifications from academics and other members of the university body, attempting to justify the use of violence as reflecting the 'sad reality is that the authorities often ignore peaceful, non-disruptive protests' (emphasis added) (see Duncan, 2016). Similarly with the discourse on the rainbow nation that when civil society organisations and community organisations protest, they tend to be ignored thus resort to violence to be heard (see for example Du Pisani, et al., 1990; Paret, 2015; Pithouse, 2016). The palatable use and normalisation of violence as a mode of engagement between the state and its citizens is deeply troubling as it begins to legitimise brutality as acceptable, valid and normal. In other words, for these academics, students' resort to violence is but a necessary condition, a clarion call to university management and the government to respond to their demands, as peaceful protest is often ignore or misunderstood. This implicit epistemic support for violence in higher education is dangerous as it seeks to re-place the central purpose of higher 
education as a place premised on the critical contestation of ideas to violence when one does not get their way or positon. Higher education ceases to be a space were diversity of thought prevails and is now characterised by protracted forms of violence as a suitable mode of engagement. Supporting this "new" form of violence in higher education, Naidoo (2016) suggests with Duncan (2016) that:

Last year I sat in a discussion in which leaders of \#FeesMustFall justified the use of violence because of the reality that many of our current political leadership have absconded or in their political arrogance have chosen to believe their own propaganda that all is fine in the Republic. My then disquiet, intensified now, was that violence is already the modus operandi of the exploding civic protests, enraged by endemic corruption and service delivery failures across townships. And that confirmed that leadership on the ground was either non-existent or discredited. And so violence from the state was responded to in kind by violence of the burning of any building that represented the state authority and often this, tragically, included schools, libraries and public buildings. Violence has de facto become the language of engagement (emphasis added) .

I do note the cognitive damage and epistemological violence that South African higher education students in general and \#RhodesMustFall students have shed a spotlight on, in calling for curricula, pedagogy and assessment to be more inclusive, democratic and socially just (see Maxwele, 2016; Naicker, 2016; Valela, 2015). For students, the teaching of an alienating curriculum, one that disregards their own indigenous/traditional education practices and ways of being, seeing and thinking, could be seen as the perpetrating epistemic violence against them (Heleta, 2016, 2018; Msila \& Gumbo, 2016). This epistemic violence, characterised by the teaching of what Pett (2015) terms "dead white men" and the need to "re-claim" curricula from them, results in the intellectual violence and marginality that students experience. For Ngcobozi (2015), Naicker (2016), and Maxwele (2016), the re-constitution of Black subjectivity and its experiences in a historically white university is seen as an institutional threat against white normativity in how to be Black is to be an epistemic liability (see also Open Stellenbosch Collective, 2015).

While I agree with the importance of tackling the different forms of epistemic racism prevalent in all facets of higher education in both historically Black and historical white universities in South Africa, violence and the use of violence, intimidation and assault have no role to play in the academic project. It is possible to offer a critique at the colonial nature of higher education in South Africa without necessarily resorting to the physical forms of violence, intimidation and assault as suggested by Kunene (2017), Ndlozi (2015), and others. The "underbelly" of the \#RhodesMustFall allows us to critically explore the often forgotten and overlooked "dark side" of the movement, which then allows us to explore to what extent, we can epistemolgiically respond in South African society in general and to higher education in particular. Tabensky and Matthews (2015) ask the question of what it means to be "be at home" in South African higher education and whose ontological subjectivity, values, beliefs, and ethics are legitimated and 
whose are marginalized and socially Othered. I argue that Tabensky and Matthews (2015) are asking the wrong question. Rather, the question should be, should we all feel "at home" in higher education? Should we not be pursuing the kind of epistemological and ontologies traditions that disrupt our understanding of the world and ourselves as well? I argue the purpose of higher education in general and South African higher education in particular should be to challenge us and our ways of seeing, being and thinking beyond our "comfort zones" so as to ensure that we are constantly unlearning and re-learning from each other.

Happing mapped the above "underbelly" of the \#RhodesMustFall movement, I now turn to introducing some of the theoretical lenses that I use, mainly Morrow' s epistemological access as both a conceptual and empirical tool to respond to the "underbelly" of the \#RhodesMustFall protests through teaching and learning.

\section{Morrow' s epistemological access}

In the early 1990s and in anticipation of the incoming democratic government, there were broad calls under the discourse of "education for all" and "right to education" in an attempt at opening the gates of higher education that were historically segregated and racialized under the apartheid regime (Badat, 1994, 2007; Morrow, 2009). Morrow argues that in these debates, there appeared what could be seen as an epistemic conflation in how demands for public education appeared to confuse access to formal education, with access to the epistemologies of the university. Access to formal education refers to the formal/physical enrolment that students undertake that allows them to fully access the university, its infrastructure, resources and others. Epistemological access, on the other hand, refers to the access to the "curriculum goods" of the university itself, that is, the curriculum, disciplinary knowledge, assumptions, epistemic values and others (Wally Morrow, 1994; Wally Morrow, 2009). For Morrow (2009: 77), epistemological access is about 'learning how to be a [successful] participant in an academic practice' and its disciplinary practices, ways of being, seeing and thinking in academia. Thus Morrow rejects the public discourse in the then 1990s that have demanded "public education" for all. Put differently, Morrow' s classical conception of epistemological access is that one cannot give, grant or even bequeath epistemological access to students. That is the sole domain and responsibility of the student to do the difficult work of grappling with curriculum knowledge, attempting to understand the material, critiquing it and finally making a contribution to the field. While I am troubled by Morrow' s acceptance of academic disciplines and fields as "pure" , "neutral" , and "apolitical" entities that are not shaped by the structures of power (see for example Morrow, 1994, 2009), I do nonetheless see value in his classical conception of epistemological access in a) arguing that we need to move beyond formal notions of access to higher education and b) to critically explore teaching and learning practices in ways that are inclusive and that facilitate epistemological access, not give it. I note the colonial nature of academic disciplines and the clarion call by scholars such as Smith (2013) and more recently Ndlovu-Gatsheni (2021) who have problematized the politics of "re-searching" Black and indigenous communities and their marginality in the colonial archive and its imagination. I 
contend that Morrow's classical notion of epistemological access constitutes an "epistemological prerequisite" before transformative and decolonial strategies could take place. Students calls for "decolonized curriculum" and fighting for "access to curriculum" knowledge should be seen as a dialogical and dialectical process - one that can be facilitated and enabled both by the academics and students in co-constructing knowledge. I now take these ideas to teaching and learning.

\section{Teaching and learning in the period of \#RhodesMustFall}

The calls by the \#FeesMustFall and \#RhodesMustFall activists in fighting for access to higher education although desirable and seemingly socially just is potentially problematic, epistemologically. This is seen in how the clarion calls by the students, similar with earlier calls by the "education for all" public discourses of the early 1990s (see Badat, 1994, 2009; Morrow, 2009) - collapses the distinction between formal access to higher education and access to the epistemologies of the university. We see this when the demand for access to the university is often confused with fighting for a 'free, decolonize higher education curriculum' (Langa, et al., 2017). For the student movement, access to the university is conceptually understood as an epistemological access into the curriculum knowledge and the discipline. This implicit collapse of access to the university on one hand with the curriculum knowledge on the hand, seeks to suggest a social justice understanding of knowledge in how students are "entitled" to the curriculum and therefore academics are ethically obligated to provide that access. Langa, et al. (2017: 10) for example, report that

The need for free education was at the heart of the \#FeesMustFall protests. Students in all the chapters argued that education must not be treated as a commodity but as a right that students are entitled to enjoy. On the other hand, university management argued that it was not possible for universities to offer free education as there was insufficient funding from government. The government argued that it was still awaiting the findings of the Commission of Inquiry into Higher Education and Training led by Justice Jonathan Arthur Heher to provide feedback on the feasibility and affordability of free higher education in South Africa. '. Students argued in all the chapters in the report that they do not simply require free education but a free education that is decolonised. It appears that students at different universities attached different meanings to the notion of a 'decolonised' education. For example, the students at the University of Limpopo argued that decolonised education means getting the same quality of education as students at historically white universities like Wits. Students at historically white universities (Wits, UCT, Rhodes and UKZN) argued that decolonised education means that the curriculum needs to be transformed to reflect the lived experiences of African people, including recognition of their scholarly work which is often on the periphery or taught as additional modules. It was argued that decolonised education means recentring the work of these scholars in the curriculum. Some universities have already started the process of transforming their 
curricula, given the concerns raised by the students during \#FeesMustFall (emphasis added).

Explaining the above shift as dialectical between the \#FeesMustFall "morphing" into \#FreeDecolonisedEducation, Maringira and Gukurume (2016: 10) report that;

Many students revealed that, in as much as the issue of \#FeesMustFall was important, just as important were the existing racial issues in South Africa, most notably the social and political-ideological distinctions between blacks and whites. Students' protests at their lack of ability to pay the current fees morphed into an interest in broader issues, including land. In their narratives they spoke about dispossession, repossession and the restoration of their lost Africanness. Their construction of African-ness was not an abstraction but rather integrally connected to the means of production, especially land. They believed that they were 'sons and daughters of the soil'. The question they asked was how they could restore their African-ness without access to and ownership of land. As such, discourses of decoloniality and African-ness were strongly tied to the curriculum and land.

In both Langa, et al. (2017)' s report and Maringira and Gukurume (2016)' s argument above, this epistemic conflation is present. However they are not the only ones, as this seems to be prevalent in the South African higher education transformation field (see for example Heleta, 2016; Mbembe, 2015; Ndlovu-Gatsheni, 2018). Collapsing the epistemic lines between access to the university with epistemological access to the curriculum socially constructs and re-presents the university in general and academics in particular as responsible for enabling access to knowledge. This, I argue, is deeply false and misleading. Academics in South African higher education are not responsible for ensuring that they stop teaching 'dead white men' (Pett, 2015) and that they induct students into "transformative knowledge" and "decolonized curricula" . Rather, the purpose of academics in South African higher education in this contested period of higher education transformation is to facilitate and enable this critical engagement in the classrooms/lecture halls/ seminar rooms, and present to students a diversity of thought, knowledge systems and Other epistemologies that ensure that students are co-constructors of knowledge and that they bring with them to the classroom, their own lived experiences, indigenous/traditional knowledge system, thoughts, beliefs and others. They ought to be engaged with what Santos (2007: ) terms the 'ecologies of knowledge' an epistemic project were we do not dismantle and re-place, but one were we re-center, re-prioritise, and re-read the word and the world from the perspective of Africa and the global South. This, I argue, will enhance the quality of the pedagogical relationship and will help enable epistemological access. Academics cannot "gift" knowledge access to students. Put differently, students are supposed to come into the classroom/seminar/lecture halls willing to do the "hard work" , do the readings, critically engage with the curriculum, show some of the limitations of the curriculum, and others. The critical engagement in the lecture halls/classroom/seminar room will ensure that 
both the academic and students are well versed on the material, know and understand it, and that they engage with the material at an abstract level. This begins the early steps of enabling epistemological access.

While I acknowledge the work from the academic development field in looking at "academic literacies" , "teaching and learning offices" , and others that are all geared towards student support in enabling students to cope with the social and academic demands of higher education (Booi, 2015; Hlatshwayo \& Fomunyam, 2019; Vorster \& Quinn, 2017), I suggest that students are not coming into our classrooms as "empty" vessels. They bring with them rich histories, indigenous/traditional knowledge, diverse perspectives/ views, beliefs and others that could all enhance the quality of the pedagogy. Thus I see the work of academic development as part of the broader university attempt that are designed to help students be better positioned to access the "curriculum goods" and knowledge in higher education.

I teach Philosophy of Education, a core module in the Bachelor of Education programme at a research intensive university in KwaZulu-Natal. One of the challenges I normally confront is when third year students critique the module as "old", "outdated" , and "antitransformation" because I insist that post-apartheid pre-service teachers understand the philosophical importance of Plato' s allegory of the cave, and the epistemic purposes of the Age of Enlightenment in Educational thought. Does that make me a colonizer? Am I dis-enabling and frustrating the potential for epistemological access to the curriculum when students refuse to read these "dead white men" under the guise of transformation? Does this conception of transformation mean epistemic erasure, that is, the intellectual silencing and marginalizing of all forms of knowledge that do not align with our racial classification and categories? Maringira and Gukurume (2016) and Ndlovu-Gatsheni (2013) refer to this as 'epistemic rupture' - that is, when previous domain theories and knowledge systems begin to replace others:

On probing what students meant by free decolonised education, they emphasised that it included renaming the university buildings, using the names of black South African heroes such as Steve Biko and Chris Hani..students asserted that decolonisation was not only about the curriculum but also about the composition of the academy - the university architecture and symbols. Consequently, the movement' s demands for decolonised and intersectional education could be construed as a communal project of resistance to Eurocentric knowledge production and consumption. Students called for knowledge embedded in local and contextual epistemologies. This is what Ndlovu-Gatsheni (2013: 46) calls an 'epistemic rupture', in which previously dominant epistemics are slowly replaced by emerging ones (emphasis added) (Maringira \& Gukurume, 2016: 38-39).

The above critique by Maringira and Gukurume (2016) and Ndlovu-Gatsheni (2013) is not a new critique. This discourse was introduced earlier by scholars within the Africanisation school of thought, were Ndlovu-Gatsheni (2013) to some extent, is drawing from. This was initially proposed by Makgoba (1996), Nase Lebakeng and Phalane (2006), and more recently Msila and 
Gumbo (2016) who have suggested a linear conception of Africanisation, one that often involved a colonial re-imagination of what it means to be African, often invoking images of traditional, " tribal" people living "peacefully" and enjoying traditional medicines before colonial contact (see for example Samuel, 2017). This simplistic essentialism and racial classification of knowledge seen also in the \#FeesMustFall movement goes against the purpose of education and it' $s$ decolonial potentiality. Scholars such as Samuel (2017), More (2008), and Appiah (2016) have critiqued this binary conceptions of scholarship that categorizes "us" and "them" / "European knowledge" / "African knowledge" and others as not only not helpful, but historically incorrect as early Greek philosophers were already drawing form the Egyptian thinkers (Appiah, 2016). Similarly with African writers/historians, they were writing/thinking/living within a global system of knowledge. Furthermore, this scholarship proposes a problematic and singular conception of what it means to be an African, collapsing all the epistemic diversities of Blackness in terms of race, gender, sexuality and others within the Black community. We are thereby classified and categorized as a singular monolithic group that has a colonial imagination of conceptualizing ourselves pre-modernity and therefore decoloniality either has to "retribalize" us back to our ancestral villages or it has to re-racialize our knowledge. These critiques, like the critiques in my module in "teaching dead white men" , therefore assumes implicitly and epistemologically, that to be Black is to be ally in thought, and that to be white in general and European in particular, is to be an existentialist threat to all our ontologies. This is misleading and constitutes a fundamental misrecognition of education, knowledge and the possibilities of enabling epistemological access.

\section{In lieu of a conclusion $\cdots$}

The challenges that confront South African higher education need to be located to the broader crisis that is facing the rainbow nation. While Archbishop Tutu' s dream of the "rainbow people of God" is still to emerge, we are still nonetheless grappling with how to make sense of the 2015-2016 student movements that have placed to our dinner tables, issues of transformation, fee-free higher education and decolonizing of curricular. In this paper, I focused largely on exploring the often overlooked "underbelly" of the \#RhodesMustFall movement, shining a spotlight on the unintended consequences of the movement which was seen with the "normalization" of militancy and violence in higher education. I purposively chose to conceptualize and focus on physical forms of violence and have left the notion of epistemological violence as part of the broader contestations of higher education.

Overall, I made two arguments. Firstly, I argued that the \#RhodesMustFall, \#FeesMustFall and others need to broaden the conception of access to higher education, to also include critical debates on the challenges of access to the epistemologies of the academy. Resulting from this argument, I then secondly argued that despite social justice and some transformation scholars telling us otherwise - epistemological access cannot be granted by academics and be given on a silver platter to students. That is the responsibility of the student together with the academics to facilitate and co-construct knowledge together in the classroom/seminar room/lecture halls. 
Access into disciplinary epistemologies, assumptions, ways of knowing, seeing and being cannot be given, granted or bequeathed by anyone. Thus, students, together with academics, need to take accountability for their own education, do the difficult work of grappling with curriculum knowledge, understanding it and offer a critique at the different ways that knowledge can be enhanced, tackled or re-conceptualized. That I argued, is how we can begin to enable and facilitate epistemological access in higher education. Thus based on the above discussion, I make the following recommendations:

- Epistemic access to curricula could result in enabling/inducting/facilitating students' access to coloniality. Future research working with the term could develop the concept to cater for what couyld be termed a "decolonial epistemic access" , one can call for a a ciritc al engagements with curricula knowledge would reinforce epistemic harm and coloniality.

- Issues of language, background, structural poverty, lack of literacy practices and other could have a significant effect on one' s ability to critically engage with the curriculum texts. Thus univeristies in general and academic staff development in particular should be at the forefont in ensuering that one' s background and oiosnality does not deprive of accessing the curriculum goods.

\section{Acknowledgements}

This work is based on research supported by the National Institute for The Humanities and Social Sciences.

\section{Author Biography}

Dr Mlamuli Nkosingphile Hlatshwayo is a scholar in the field of Higher Education and Politics. He is a Senior Lecturer in the discipline of Curriculum Studies at the School of Education at the University of KwaZulu-Natal. He holds a PhD in Higher Education Studies and a Masters' Degree (Cum Laude) in Political Studies from Rhodes University.

\section{References}

Alasow, J. 2015. What about 'Rhodes (University) must fall' ? Daily Maverick, 23 March. Available at: https://www.dailymaverick.co.za/opinionista/2015-03-23-what-aboutrhodes-university-must-fall/ (accessed: 2 February 2021).

Appiah, K.A. 2016. There is no such thing as western civilisation. The Guardian, 9 November. Available at: https://www.theguardian.com/world/2016/nov/09/western-civilisationappiah-reith-lecture. (accessed: 2 February 2021).

Badat, S. 1994. Differentiation and Disadvantage: The Historically Black Universities in South Africa: Report to the Desmond Tutu Educational Trust. Education Policy Unit, University of Western Cape.

Badat, S. 2007. Higher Education Transformation in South Africa Post 1994: Towards a Critical Assessment. CEPD. 
Badat, S. 2009. Theorising institutional change: post-1994 South African higher education. Studies in Higher Education, 34(4): 455-467.

Badat, S. 2017. Trepidation, longing, and belonging: Liberating the curriculum at universities in South Africa. Invited keynote address for Public Lecture Series on Curriculum Transformation Matters: The Decolonial Turn.

Baines, G. 1998a. The rainbow nation. Identity and nation building in post-apartheid South.

Baines, G. 1998b. The rainbow nation? Identity and nation building in post-apartheid South Africa. Mots pluriels, 7: 1-10.

Baines, G. 2007. The politics of public history in post-apartheid South Africa. History making and present day politics: The meaning of collective memory in South Africa, 167-182.

Beall, J., Gelb, S. \& Hassim, S. 2005. Fragile stability: State and society in democratic South Africa. Journal of Southern African Studies, 31(4): 681-700.

Bond, P. 2014. Elite Transition: From Apartheid to Neoliberalism in South Africa. London: Pluto Press.

Booi, M. 2015. Accelerated development programmes for Black academics: Interrupting or reproducing social and cultural dominance. Unpublished Master' $s$ thesis, Rhodes University, South Africa.

Chikane, R. 2018. Young people and the\# Hashtags that broke the rainbow nation. In Pickard, S. \& Bessant, J. (eds.)Young People Re-Generating Politics in Times of Crises. London: SPringer: 19-39.

Du Pisani, J., Broodryk, M. \& Coetzer, P. 1990. Protest marches in South Africa. The Journal of Modern African Studies, 28(4): 573-602.

Duncan, J. 2016. Why student protests in South Africa have turned violent. The Conversation, 29 September. Available at: https://theconversation.com/why-student-protests-in-southafrica-have-turned-violent-66288 (accessed: 2 February 2021).

Fanon, F. 1963. The Wretched of the Earth. London: Penguin Books.

Heleta, S. 2016. Decolonisation of higher education: Dismantling epistemic violence and Eurocentrism in South Africa. Transformation in Higher Education, 1(1): 1-8.

Heleta, S. 2018) Decolonizing knowledge in South Africa: Dismantling the 'pedagogy of big lies' . Ufahamu: A Journal of African Studies, 40(2).

Hlatshwayo, M.N. \& Alexander, I. 2021. 'We' ve been taught to understand that we don' t have anything to contribute towards knowledge': Exploring Academics' understanding of decolonising curricula in higher education. Journal of Education, (82): 44-59.

Hlatshwayo, M.N. \& Fomunyam, K.G. 2019. Views from the margins: Theorising the experiences of black working-class students in academic development in a historically white South African university. The Journal for Transdisciplinary Research in Southern Africa, 15(1): 11.

Kunene, A. 2017. The 'Rainbow Nation' Made Us Believe That Even Within Our Differences We Are Equal -- But We Are Not. Huffington Post, 22 August. Available at: https://www.huffingtonpost.co.uk/ashanti-kunene/the-rainbow-nation-made-us- 
believe-that-even-within-our-differences-we-are-equal-but-we-are-not_a_23079188/ (accessed: 2 February 2021).

Langa, M., Ndelu, S., Edwin, Y. \& Vilakazi, M. 2017. \# Hashtag: An Analysis of the\# FeesMustFall Movement at South African Universities.Africa Portal, 1 January. Available at: https://www.africaportal.org/publications/hashtag-an-analysis-of-the-feesmustfallmovement-at-south-african-universities/ (accessed: 2 February 2021).

Makgoba, W. 1996. South African universities in transformation: Africanise or perish. Politeia, 15(2): 114-118.

Manzini, Z. 2016. Violence is a necessary process of decolonisation. Mail \& Guardian, 2 March. Available at: https://thoughtleader.co.za/mandelarhodesscholars/2016/03/02/violence-isa-necessary-process-of-decolonisation/ (accessed: 2 February 2021).

Maringira, G. \& Gukurume, S. 2016. Being Black' in \#FeesMustFall and \#FreeDecolonisedEducation: Student protests at the University of the Western Cape. In Langa, M. (ed.) An Analysis of the \#FeesMustFall Movement at South African Universities. Centre for the Study of Violence and Reconciliation, 33-48.

Mashele, P. \& Qobo, M. 2014. The Fall of the ANC: What Next? Johannesburg: Picador Africa.

Maxwele, C. 2016. Black pain led me to throw Rhodes poo. Business Day, 16 March. Available at: https://www.businesslive.co.za/bd/opinion/2016-03-16-black-pain-led-me-to-throwrhodes-poo/ (accessed: 2 February 2021).

Mbembe, A. 2015. Decolonizing knowledge and the question of the archive. Aula Magistral Proferida.

Mbembe, A. 2016. Decolonizing the university: New directions. Arts and Humanities in Higher Education, 15(1): 29-45.

More, M.P. 2008. Biko: Africana existentialist philosopher. In Mngxitama, A., Alexander, A. \& Gibson, N.C. (eds.) Biko Lives! New York: Palgrave Macmillan, 45-68.

Morrow, W. 1994. Entitlement and achievement in education. Studies in Philosophy and Education, 13(1): 33-47.

Morrow, W. 2009. Bounds of Democracy: Epistemological Access in Higher Education. The Human Sciences Research Council.

Msila, V. \& Gumbo, M.T. 2016. Africanising the Curriculum: Indigenous Perspectives and Theories. Stellenbosch: African Sun Media.

Naicker, C. 2016. From Marikana to\# feesmustfall: The praxis of popular politics in South Africa. Urbanisation, 1(1): 53-61.

Naidoo, J. 2016. Guilty as charged: Burning universities are a mirror of our country. Daily Maverick, 9 October. Available at: https://www.dailymaverick.co.za/opinionista/2016-10-09-guiltyas-charged-burning-universities-are-a-mirror-of-our-country/ (accessed: 2 February 2021).

Nase Lebakeng, J.T. \& Phalane, M.M. 2006. Epistemicide, institutional cultures and the imperative for the Africanisation of universities in South Africa. Alternation, 13(1): 70-87.

Ndlovu-Gatsheni, S. 2013. Decolonising the university in Africa. The Thinker, 51: 46-51. 
Ndlovu-Gatsheni, S. 2018. Epistemic Freedom in Africa: Deprovincialization and Decolonization: London: Routledge.

Ndlovu-Gatsheni, S. 2021. Internationalisation of higher education for pluriversity: a decolonial reflection. Journal of the British Academy, 9(s1): 77-98.

Ndlozi, M. 2015. In defence of black violence. Daily Maverick, 31 August. Available at: https://www.dailymaverick.co.za/opinionista/2015-08-31-in-defence-of-black-violence/ (accessed: 2 February 2021).

Ngcobozi, L. 2015. \#RhodesSoWhite: An Insight. The Con, 27 March. Available at: http://www.theconmag.co.za/2015/03/27/rhodessowhite-an-insight/ (accessed: 2 February 2021)

Nicolson, G. 2016. UJ arson: University gets interdict while no aggrieved parties claim responsibility. Daily Maverick, 17 May. Available at: https://www.dailymaverick.co.za/article/2016-05-17-uj-arson-university-gets-interdictwhile-no-aggrieved-parties-claim-responsibility/\#.WA6HsPkrJpi (accessed: 2 February 2021).

Njilo, N. 2019. Chaos as Wits students protest over accommodation, debts. Times Live, 4 February. Available at: https://www.timeslive.co.za/news/south-africa/2019-02-04-chaos-as-witsstudents-protest-over-accommodation-debts/ (accessed: 2 February 2021).

Open Stellenbosch Collective. 2015. Open Stellenbosch—tackling language and exclusion at Stellenbosch University. Daily Maverick, 28 April. Available at: https://www.dailymaverick.co.za/article/2015-04-28-op-ed-open-stellenbosch-tacklinglanguage-and-exclusion-at-stellenbosch-university/ (accessed: 2 February 2021).

Paret, M. 2015. Violence and democracy in South Africa's community protests. Review of African Political Economy, 42(143): 107-123.

Pett, S. 2015. It' s time to take the curriculum back from dead white men. The Conversation, 8 May. Available at: https://theconversation.com/its-time-to-take-the-curriculum-backfrom-dead-white-men-40268 (accessed: 2 February 2021).

Pillay, K. 2018. Students attack lecturers. News 24, 9 July. Available at: https://www.news24.com/SouthAfrica/News/students-attack-lecturers-20180709 (accessed: 2 February 2021).

Pithouse, R. 2016. Writing the Decline: On the Struggle for South Africa's Democracy. Johannesburg: Jacana Media (Pty) Limited.

Samuel, M.A. 2017. Africanising the curriculum: Indigenous perspectives and theories by Vuyisile Msila and Mishack T. Gumbo (Editors). Educational Research for Social Change, 6(1): 8792.

Samuel, M. A., Dhunpath, R. \& Amin, N. 2017. Disrupting Higher Education Curriculum: Undoing Cognitive Damage. London: Springer.

Santos, B. d. S. 2007. Beyond abyssal thinking: From global lines to ecologies of knowledges. Binghamton University Review, 30(1): 45-89. 
Sizemore-Barber, A. 2020. Prismatic Performances: Queer South Africa and the Fragmentation of the Rainbow Nation: Ann Arbor: University of Michigan Press.

Smith, L.T. 2013. Decolonizing Methodologies: Research and Indigenous Peoples. London: Zed Books Ltd.

Tabensky, P.A. \& Matthews, S. 2015. Being at Home: Race, Institutional Culture and Transformation at South African Higher Education Institutions. Pietermaritzburg: University of KwaZulu-Natal Press.

Valela, N. 2015. The Rhodes to perdition: Why Rhodes was never ready for the BSM. Daily Maverick, 26 March. Available at: https://www.dailymaverick.co.za/opinionista/2015-0326-the-rhodes-to-perdition-why-rhodes-was-never-ready-for-the-bsm/ (accessed: 2 February 2021).

Vorster, J.-A. \& Quinn, L. 2017. The" decolonial turn": what does it mean for academic staff development? Education as Change, 21(1): 31-49.

Wa Azania, M. 2014. Memoirs of a Born Free: Reflections on the Rainbow Nation. Sunnyside: Jacana Media.

Wa Azania, M. 2016. Burning of universities is counter-revolutionary. IOL, 22 May. Available at: https://www.iol.co.za/sundayindependent/burning-of-universities-is-counterrevolutionary-2024543 (accessed: 2 February 2021). 